\title{
LOYALTY PROGRAMS AS PART OF COMPANY'S MARKETING STRATEGY
}

\author{
K. Mrkosová, O. Dufek, L. Majer
}

Received: December 17, 2010

\begin{abstract}
MRKOSOVÁ, K., DUFEK, O., MAJER, L.: Loyalty programs as a part of company's marketing strategy. Acta univ. agric. et silvic. Mendel. Brun., 2011, LIX, No. 2, pp. 199-204

This paper aims to characterize the current status of using customer loyalty programs in the Czech Republic. Customer loyalty programs are evaluated as a part of marketing communication, where especially customer cards have a specific role in communication mix of selected companies. Furthermore, customer loyalty programs are evaluated from the perspective of internal marketing system company, as an invaluable source of data about customers. Obtained data are used for decisions on segmentation, targeting and overall marketing strategy. Customer loyalty programs in the Czech Republic are also examined from the perspective of consumers - factors that influence consumer involvement in these programs are evaluated. The paper also shows the results of desk research about personal information provided by consumers to engage in customer loyalty programs.
\end{abstract}

loyalty program, loyalty card, consumer, personal data

The importance of brand building and emotional benefits that are important to establish strong relationships with customers is constantly growing, mainly due to decreasing disparities in the quality of the products that are becoming commonplace. According to Šilerová (in Intuitivní marketing, 2010) the number of companies realizing this situation is sufficient in the Czech Republic. To differentiate product using other differentiation, such as emotional associations, which are hardly to copy by competitors, is necessary. For example loyalty programs can help with building this differentiation.

The survey conducted in the Slovak Republic, 2008 (Nagyová, Stávková, Tonkovičová, 2008) indicates that $31.3 \%$ of respondents hold a loyalty card and the most visited retail network is Tesco. More than 630000 families in the Slovak Republic is currently using Tesco Clubcard loyalty card. In Great Britain, where the Tesco loyalty program started, more than 15 million Clubcards is owned by customers. Tesco loyalty program in the Czech Republic has started at September 2010. During the first two months more than 900,000 of the company's loyalty card were issued to local customers (Strategie, 2010). This shows the huge interest among consum- ers about this type of sales promotion. Tesco loyalty program will likely exceed the expectations established by experience of Slovakia, that there will be one million customers involved in this loyalty program within one year after starting the program in the Czech Republic (ČTK in Finanční noviny, 2010).

The power of loyalty programs is in inducing the consumer who has once purchased a product of a particular company, to become a regular customer, to create long-term relationship between him and the seller. The customer has to engage the loyalty program (usually to obtain loyalty card) and convey identification data as well as other information related to consumer preferences. Thanks to the loyalty card gets benefits such as discounts, bargains and in many cases gain points as a cost. This can also include free shipping on orders over a certain threshold, continuous customer service (green line), free or privileged information and news collection or a gift for some purchase of goods and so on. These advantages shall stimulate consumer for further purchases.

Loyalty programs are considered as a form of active participation of direct customers to company presentations - thus creating a stable circle of cli- 
ents. The result of loyalty programs is a long-term increase of demand based on consumer decision to prefer consumer loyalty program provider. (ImperialMedia, 2009). Loyalty Program is than a marketing tool used to strengthen the loyalty of existing customers and build the trust with the future ones. According to the provided benefits Matula (2007) divides loyalty programs as:

- Gifts loyalty programs - free gifts and free samples.

- Discount loyalty programs - discount on next purchase, discounts, vouchers for goods, reduced prices, etc.

- Rebate loyalty programs - discount for goods at exact value.

- Combined loyalty programs - consumers becomes a member of loyalty club often represented by loyalty card where points are collected. Consumers can choose whether to take gift items, run a discount, or use points to purchase additional goods. Loyalty programs are directed to the end customer (consumer loyalty programs) or to the retailer (trade loyalty programs). The article will deal with customer loyalty programs.

The crucial facts reflecting the benefits of customer loyalty programs for companies are (Kotler and Keller, 2007; Matula, 2007; Přikrylová and Jahodová, 2010):

- Establishing good relationships with existing customers.

- Building trust and continuous business relations with customers.

- Acquiring new customers who otherwise have no interest for offered products or services.

- Increase of consumer motivation for buying, sales promotion.

- Strengthening its market position.

- Raise awareness about the company.

- Gaining a competitive advantage.

- Increase attendance.

The threat of loyalty programs may not be the satiation of consumers by incentives to use the existing loyalty card, but the beginning of consumer immunity to offers for signing up for other loyalty programs. This is probably caused by similar loyalty programs across the market. data

Companies and their loyalty programs - current

In times of economic crisis, the companies began looking for new ways of cost cutting. Opposite to the trend of increasing popularity of loyalty programs, only $20 \%$ of companies in the telecommunications sector in a survey by the British GI Insight (database marketing and consumer behavior research) said that loyalty programs are fully integrated into their marketing plan. Loyalty is in the IT industry, where customers are highly unstable, and an essential ele- ment. $97 \%$ of marketers in this sector are considered, loyalty programs as an increasingly important tool of a successful business in the past two years (iDIRECT, 2010).

America is the cradle of loyalty programs, in the U.S. loyalty marketing has reached the age of maturity $-75 \%$ of retailers are managing at least one loyalty program. The following figures show the global expansion of loyalty programs (Póčová, 2008):

- More than $76 \%$ of all retailers in the U.S. with more than 50 shops are offering so-called "frequentshopper program" (Report The Food Marketing Institute).

$40 \%$ of all merchants accepting payment cards such as Visa and Master Card are engaged in loyalty programs (Cardweb.com).

- 70\% of Canadian households are involved in the Air Miles loyalty program. Every 8th Swede, including infants and elderly is member of the IKEA Family loyalty program.

- Every 3rd German household is a member of Payback loyalty program.

- 11 million United Kingdom inhabitants are members of the Nectar loyalty program.

$45 \%$ of midsize firms in North America are involved in one of the loyalty programs ran by their suppliers (Warrillow and Associates).

- There are 89 million members worldwide of airline frequent flyer programs (Web Flyer).

Server eMarketer.com conducted a survey question why companies offer customer loyalty programs. For half of the respondents the first answer is that loyalty programs can maintain a strong group of high-value customers (making significant part of income). The second most frequent reason was using customer's data for better segmentation and targeting. An effort to reduce consumer wear was in third place (Kern, 2010). Increasing interest (highest for last 10 years) for loyalty cards in the Czech Republic is confirmed by the loyalty card vendor Cardhouse Ltd., over $40 \%$ of Billa customers are members of Billa loyalty program. (Kučerová, 2009). Toman (2010) states in his paper that the companies refusing loyalty programs substantiate their decision with arguments of wide assortment, low prices and local stores. Offer customer loyalty cards to all customers with the same discount are the easiest solution, but less effective (Peterský, 2009).

\section{Privacy Policy}

The customer has to declare not only identification data but also other information related to consumer preferences to engage the loyalty program (usually to obtain loyalty card). Personal data inform about the person, his/her hobbies and habits, characteristics and attitudes and financial circumstances. They may also convey information about relation-

1 According to American Express Market Brief (2007) 28\% of customers claim to be "most happy" for having customer loyalty card of their retailer. 
ships with other people, the health status and life style. Data disrupting privacy are called sensitive (ƯOSÚ, 2004). Name, surname, address and date of birth are required data for Tesco Clubcard admittance. Examples of the optional information are whether the person concerned in loyalty program is a vegetarian, diabetic, or on a diet. Law on personal data protection is in force since 2000 , but dealers still fail to comply adequately with the personal data provided by customers for which they can be fined by the Office for the Protection of personal data. Therefore it is necessary to inform the customer about purpose and content of collected data (Kusáková In Intuitivní marketing, 2010).

\section{MATERIALS AND METHODS}

All the data were obtained during September and October 2010 using mainly desk research based on searching the web (e.g. Google, Seznam) for subsequent keywords: loyalty program, loyalty card and consumer program, to find companies offering customer loyalty programs in the Czech Republic. The results of the first phase were than supplemented with the field research among retailers in Brno (mainly center of the city and shopping centers). There were data about 68 companies offering loyalty program collected ${ }^{2}$. The types of data collected are following: information required about customer to join the loyalty program (name, surname, address, phone, sex, date of birth, e-mail) and information about offered benefits (gifts, discounts, collect- ing points and other). Finally all the companies were contacted via e-mail with questions about their loyalty program, such as the date of the launch.

\section{RESULTS}

Loyalty programs can be found in many areas of everyday life, provided by wide range of retailers with consumer goods due to its nature and manner of use. Most of loyalty programs are related to everyday consumer goods and services, in particular range of foods, drugstore goods and clothing. In services category auto-moto and lifestyle are well represented. Consumer loyalty programs are mainly useful for companies with broad chain store and/or complex product mix.

Despite increasing computer literacy most of the surveyed organizations preferred face-to-face communication when registering new clients in their loyalty programs and registration must be made at the branch or store. The influence of the Internet, however, is negligible. Much of the surveyed firms offer a variety of internet or personal registration. Finally it is up to the user to choose the right method of registration. For entering loyalty program consumer is usually asked to fill out a registration form containing selected personal data and information processing agreement. Some of interviewed subjects are using a kind of "pre-registration" system, where customer owns "temporary loyalty card" that allows consumer collect points for every purchase in selected stores. Full-fledged membership to the

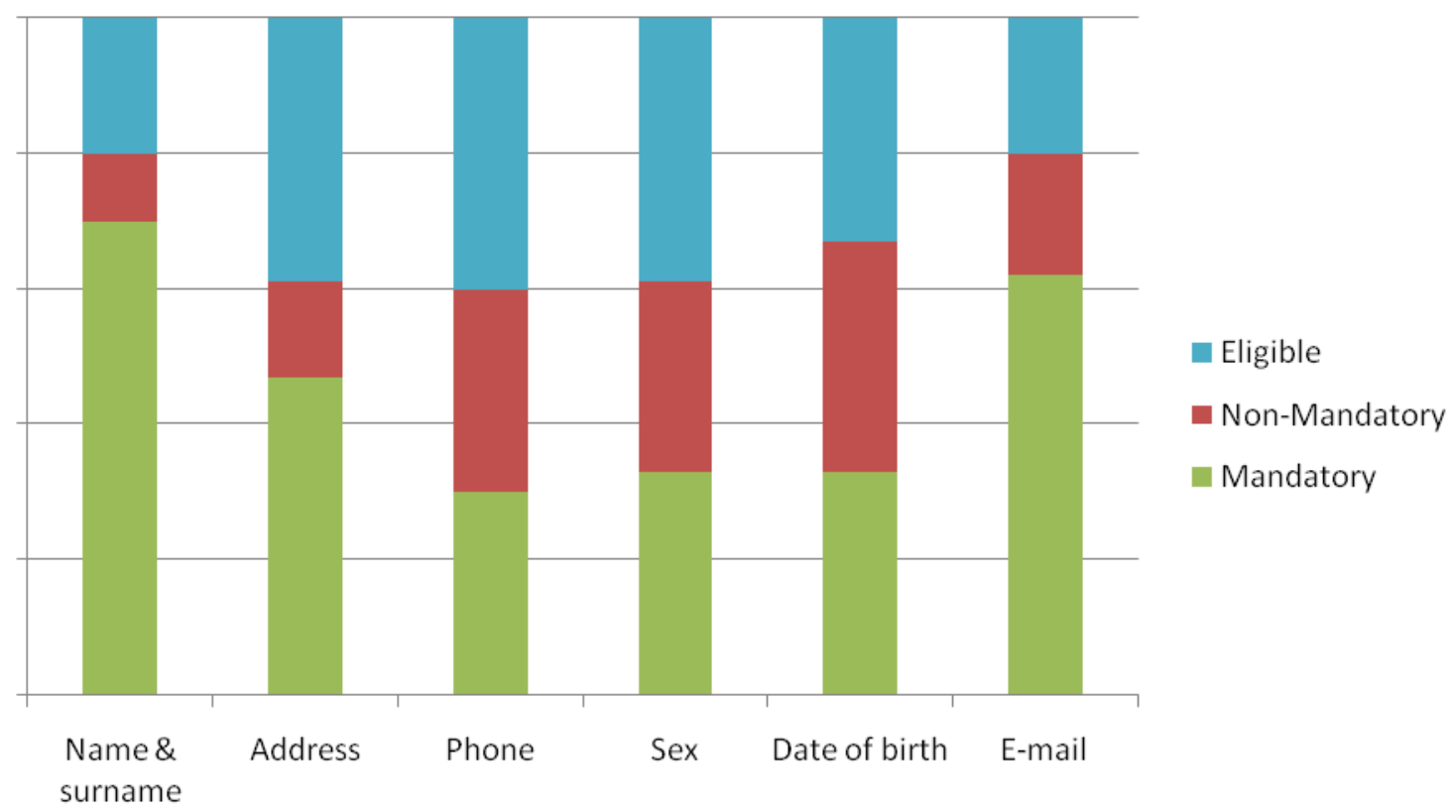

1: Types and level of mandatory of obtained data

2 For example: A3 Sport, AXA, Agip, Alpine Pro, Bata, ČEPRO, Česká pošta, Česká spořitelna, Computer Press, ČSA, DM, Kenvelo, Killtec, Klenoty AURUM, Marks \& Spencer, NC Královo Pole, Shell, Sixt, Sphere, Student Agency, Tchibo, Tesco, Tipsport, T-Mobile, Yves Rocher, etc. 
loyalty program is provided in condition of submitting the registration form and subsequently a fullfledged membership card is issued to customer.

Considerable majority of companies contacted requires at least the basic personal information such as name, address and e-mail contact from future members of loyalty program. The company requires a name and surname (often in conjunction with an address), especially in those cases where the type of the loyalty card is non-transferable membership card tied to a specific person. Roughly a third of examined firms denote these data as non-mandatory or eligible. This is typical for portable loyalty cards, various types of discount cards received by a onetime purchase of a certain amount or a specially issued discount cards. Phone number is required by approximately one third of surveyed firms. The Fig. 1 shows what type of data are required as mandatory, non-mandatory and eligible. About two thirds of companies have phone number as a mandatory information. In contrast, e-mail contact is required nearly by three-fifths of companies. It is probably because, it is much cheaper to contact consumer via email (electronic communication is considered as an inexpensive and effective way), and you can make your communication more remarkable. It is a direct channel to consumers via they can get updated information about upcoming news or discount in the range of events. E-mail is easier to fake on the other hand. It is indicated as a totally optional in about $20 \%$ of the examined subjects.

An interesting fact is that every third company does not give weight to the client's date of birth. It is mandatory or optional entry for the rest. About one third of respondents require sex a mandatory - however this indication is used mainly to correct client address in written or electronic communication, which the company is mainly used to send information about news. For one third of the subjects on the contrary, this information is completely uninteresting, and in $40 \%$ of the cases it depends on the willingness of customers, whether publish that in- formation or not. In some cases, the customer is rewarded for completing sensitive personal information such as phone number or e-mail address with one-off bonus of plus points.

More than half of surveyed loyalty programs based on collecting points earn for every purchase, which can then redeem for various rewards and / or gifts that are offered to customers through various forms of rewards newsletters or catalogs (in printed or electronic version). Five of all programs reward their members during their membership with different forms of gifts such as a birthday gift, an invitation to corporate event or permission to enter special events (often single). This form of remuneration is evident especially in those programs, whose members are creditworthy clients.

Significant part of loyalty programs reward customers for purchasing goods with various types of discount schemes, which are primarily based on customer loyalty to the company / brand. With the growing number of purchases and thus a higher number of points collected, the customer gets higher discount that can be applied further. These programs are less frequently used, but are designed primarily for companies that have a wide range of customers. Such programs have several levels - usually the 3 basic levels:

1. level (essential, basic, standard) - the card is issued to the customer upon request at the store or via the Internet, and allows him / her to join the scheme.

2. level (advanced, silver) - customers with stated amount of points collected can enter second level and obtain new card, which entitles him to draw higher discounts than in level one.

3. level (the top programs, gold / platinum cards) - are designed for very loyal customers and offer senior discounts as well as various other forms of rewards such as priority checkin, VIP invitations to corporate events, etc.

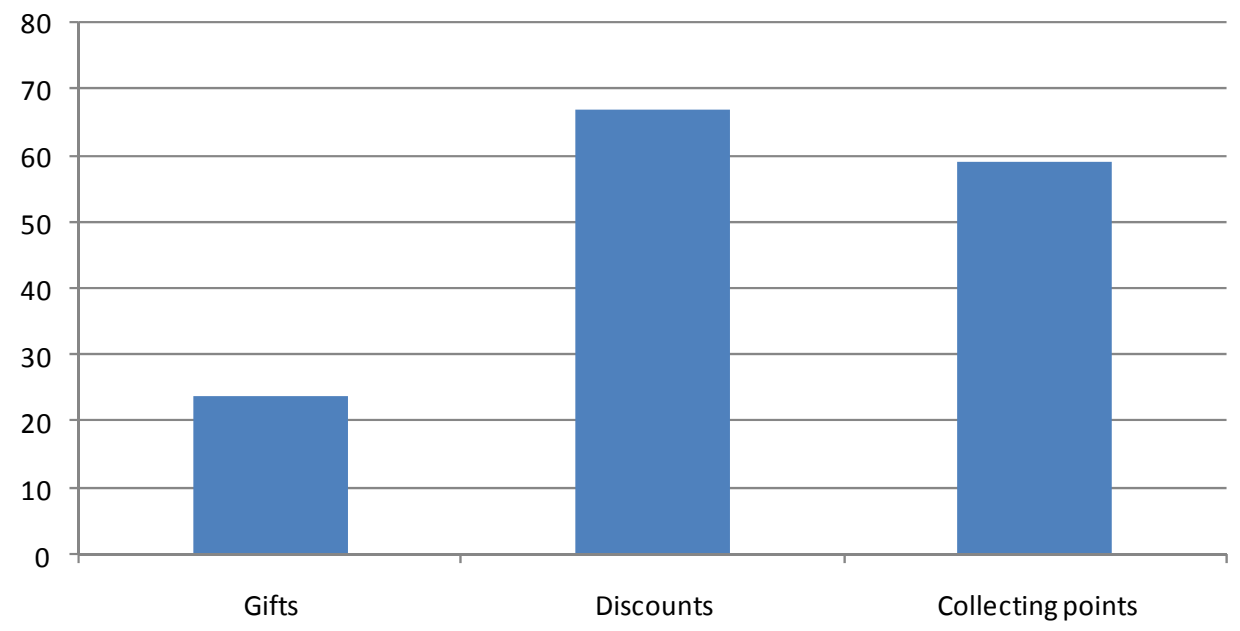

2: Number and type of benefits in loyalty programs 


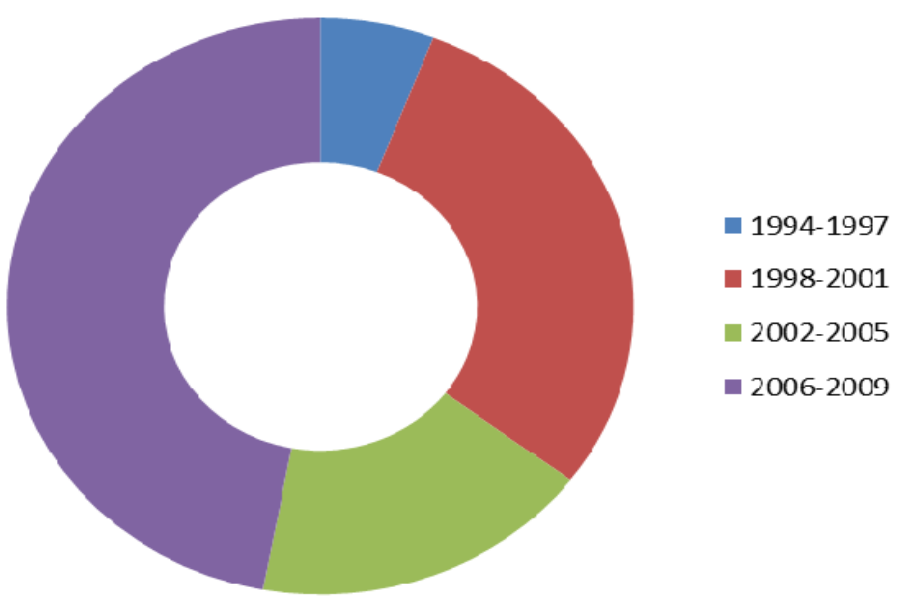

3: Year of loyalty program establishement in examined companies

Most companies that use loyalty programs to which they are able to establish cooperation, Newsletter or any other type of frequent communication about news in the company or loyalty program is very often in surveyed companies. This information is mainly distributed electronically via Internet, which is currently considered to be a fast, cheap and effective way to communicate. Consumers, who shared register their contact details (particularly email contact) get an opportunity to be informed about news, not only from within the company, but also has the opportunity to be informed about the events in stores that are closer to them.

As already noted, much of the loyalty program is based on collecting items that the customer is then able to exchange for various rewards. These points in some programs have limited duration and must be exchanged for rewards points in the period of validity.
Use these programs less than 5 years. The vast majority of loyalty programs were created after 2000 .

By obtained data from marketing research we can determine what are the main periods the loyalty programs were mainly established. This is visualised by Fig. 3. As we can see the most frequent loyalty programs were established in recent years. About half of the companies included in this research uses loyalty programs since 2006 or later. By contrast, only a third of firms than others, which were part of research, is collecting data from loyalty programs more than 10 years - mainly in period 1998 to 2001. The first companies form the research sample started offering loyalty programs in 1994.

This proofs loyalty programs are not a new type of marketing tools, but their popularity is rising in last 5 years.

\section{SUMMARY}

Loyalty programs are considered as a form of active participation of direct customers to company presentations - thus creating a stable circle of clients. The result of loyalty programs is a long-term increase of demand based on consumer decision to prefer consumer loyalty program provider.

All the data were obtained during September and October 2010 using mainly desk research based on searching the web for subsequent keywords: loyalty program, loyalty card and consumer program. The results of the first phase were than supplemented with the field research among retailers in Brno. There were data about 68 companies offering loyalty program collected. Finally all the companies were contacted via e-mail with questions about their loyalty program, such as the date of the launch. Most of the loyalty programs that are in use are not older than five years and almost all (more than 65\%) were established after 2002. The most frequent mandatory information obtained from consumer is: name and surname (70\%), e-mail (62\%), address, sex, date of birth and phone. The most eligible ones are phone and sex (mandatory in only around 30\%). Rewards typically come from one of these areas (in order of number): discounts (67\%), points (59\%) or gifts (23\%). There are companies with wide range of offering goods, which are divided their programs into three levels with different types of rewards. Names of the levels are typically essential, basic or standard for level 1 , advanced or silver for level 2 and top, platinum or gold for level 3. Occurrence of these companies was very low. 
Acknowledgement

The paper has been written with the support of the project for the Czech Ministry of Education, Youth and Sports MSM 6215648904 Česká ekonomika v procesech integrace a globalizace a vývoj agrárního sektoru a sektoru služeb v nových podmínkách evropského integrovaného trhu.

\section{REFERENCES}

ČTK, 2010: Tesco spustísystém vérnostních karet Clubcard. Finanční noviny [online]. 26.08.2010 [cit. 2010-1115]. Dostupný z www: 〈http://www.financninoviny.cz/ zpravy/tesco-spusti-system-vernostnichkaretclubcard/520219\&id_seznam $=>$.

Úrad pro ochranu osobnich údajio, 2004: [online]. Chraňte své soukromí![cit. 2010-11-15]. Dostupný z www: 〈http://www.uoou.cz/files/letak.pdf $>$.

Jak nakládáte s osobnimi údaji svých zákazníkư? Intuitivní marketing [online]. 16. 6. 2010 [cit. 2010-11-15]. Dostupný z www: <http:// www.intuitivnimar keting.cz/marketing/jak-nakladate-s-osobnimi-udaji-svych-zakazniku>.

KERN, I., 2010: Vérnostní programy jako datakopové. Marketing journal [online]. 2.2.2010 [cit. 2010-1115]. Dostupný z www: <http://www.m-journal. cz/cs/reklama-podpora-prodeje/vernostni-programy-jako-datakopove_s278x6120.html>.

KUČEROVÁ, D., 2009: Kolik zákaznických karet se vejde do peněženky? Podnikatel.cz [online]. 18. 8. 2009 [cit. 2010-11-15]. Dostupný z www: <http://www. podnikatel.cz/ clanky/kolik-zakaznickych-karetse-vejde-do-penezenky/>.

Kolektiv autorů, 2010: Loajalita zákazníkư v České republice. Intuitivní marketing [online]. 13.9.2010 [cit. 2010-10-24]. Dostupný z www: <http://www. intuitivnimarketing.cz /marketing/loajalita-zakazniku-v-ceske-republice $>$.

NAGYOVÁ, L'., STÁVKOVÁ, J., TONKOVIČOVÁ,Z., 2008: Selected characteristics of Slovak Consumers Purchasing Behavior. Acta Universitatis Agricul- turae et Silviculturae Mendelianae Brunensis. 2008, LVI, 6, p. 69-76.

PETERSKÝ, J., 2009: Kdy nám vèrnostní program vrátí prostredky v podobé loajálních zákazníkư? Marketing journal[online]. 16.12.2009, 111, [cit. 2010-1115]. Dostupný z www: <http://www.m-journal.cz/ cs/reklama-podpora-prodeje/podpora-prodeje/ kdy-nam-vernostni-program-vrati-prostredky-vpodobe-loajalnich-zakazniku_s394x5897.html>

PÓČOVÁ, K., 2008: Vérnostní programy pro 21. století. Strategie.cz [online]. 5.5.2008 [cit. 2010-11-15]. Dostupný z www: <http://www.strategie.cz/ scripts/detail.php?id=357657 $>$.

Strategie.cz [online]. 19.11.2010 [cit. 2010-1121]. Věrnostní program Tesco má 900000 lidí. Dostupné z www: <http://www.strategie.cz/ scripts/detail.php?id=500155>.

Telco autility sektorpotvrzují význam vérnostních programů, často však chybí vétši integrace. iDIRECT[online]. 19.3.2010 [cit. 2010-11-15]. Dostupný z www: <http: // idirekt.cz/marketingove-zpravodajstvi/ telco-a-utility-sektor-potvrzuji-vyznam-vernostnich-programu-casto-vsak-chybi-vetsi-integrace $>$.

TOMAN, M., 2010: Kudy by se mèly ubirat vèrnostní programy? Marketingové noviny [online]. 11.1.2010 [cit. 2010-11-15]. Dostupný z www: $<$ http://www.marketingove noviny.cz/index. php3?Action=View\&ARTICLE_ID=8087> .

Vérnostní programy. [online]. 2009 [cit. 2010-11-15]. ImperialMedia s.r.o. Dostupné z www: <http:// www.imperialmedia.cz/komunikace-a-planovani/vernostni-programy $>$.

Ing. Klára Mrkosová, Ing. Ondřej Dufek, DiS., Luděk Majer, Ústav marketingu a obchodu, Mendelova univerzita v Brně, Zemědělská 1, 61300 Brno, Česká republika, e-mail: klara.mrkosova@mendelu.cz, xdufek@ mendelu.cz,xmajerl@mendelu.cz 